\title{
Frustrated Leadership: Russia's Economic Alternative to the West
}

\section{Juliet Johnson and Seçkin Köstem}

\section{Abstract}

The Russian government saw the 2008 global financial crisis as both a repudiation of western neoliberalism and as an ideal opportunity to promote its own international economic leadership. Russia's alternative vision encompasses multipolarity, financial nationalism and political illiberalism. These policies are symbiotic. The state uses its control over financial flows to build and maintain political and economic power at home as well as to project its influence abroad, all justified with a strong dose of great power nationalism positioning Russia as the Eurasian pole in an emerging multipolar world order. However, the Kremlin is doomed to frustration in its quest to assert international economic leadership. The Russian government has the ability to shake up the existing international order but lacks the credibility, stability, or economic clout to lead the creation of a new one. This has troubling implications for the future of international economic cooperation and reform, as Russia's frustrations have increasingly turned it in reactive and confrontational directions.

\section{Policy Implications}

- The west must devise a new strategy towards Russia - one that takes into account Russia's search for great power status and Eurasian leadership without at the same time undermining international economic cooperation or forcing Russia's smaller neighbors to choose sides.

- To this end, the US should play a more constructive and cooperative role in meaningful reform of the international financial architecture, especially as regards the International Monetary Fund (IMF).

- Given the mismatch between Russia's aspirations and capabilities, the Russian government's attempts to develop the Eurasian Economic Union (EEU), build up Brazil, Russia, India, China and South Africa (the BRICS) group, and devise alternative nonwestern financial institutions should be understood as signs of economic weakness rather than strength.

- China, the US, and the EU should work together to discourage financial nationalism in Russia and protectionism in the new EEU, policies that are potentially damaging for all sides.

The global financial crisis fundamentally challenged the western-led international economic order. The insolvency of major US financial institutions, the worldwide contagion effects, and the existential crisis of the European project and the euro revealed the inadequacies of existing financial regulatory regimes. On a deeper level, the crisis called into question the ability of the western economic model - liberal democracy, light-touch regulation, and an international financial infrastructure guided by institutions like the International Monetary Fund (IMF) and fueled by US dollars - to drive global prosperity and stability. Yet despite widespread postcrisis dissatisfaction with the international order, concrete change at the international level has remained so anemic that Eric Helleiner (2014) has referred to the 'status quo crisis' and Colin Crouch (2011) has puzzled over the 'strange nondeath of neoliberalism.'

Russian political elites have been among the most critical of the slow pace of systemic change. The Russian government saw the global financial crisis not only as a repudiation of western neoliberalism, but also as an ideal opportunity to promote its own international leadership and economic vision. Ever since the Soviet collapse, Russian leaders had searched for a new global role for Russia. The financial crisis and its aftermath gave the Russian government under Vladimir Putin the chance to advance ideas on global economic leadership that had long been percolating in the Russian foreign policy community.

Russia's alternative vision clusters around two major economic themes: multipolarity and a state capitalism laced with financial nationalism. Multipolarity is an updated interpretation of the realist concept of spheres of influence, with several 'pole' powers constructing regional multilateral institutions and relationships as alternatives to western-dominated, universalist international institutions. Multipolarity does not rule out cooperation with the west or with western institutions, but insists that this occurs with the pole powers on an equal footing and with a mutual respect for their different regional security and economic interests. Advocates of multipolarity often give it a nationalist or civilizationalist spin as well, arguing that less powerful states should gravitate towards particular poles based on cultural and historical affinities. 
State capitalism - government direction of the 'commanding heights' of the economy within a broader capitalist framework - has a long international history and enjoyed a global resurgence after the financial crisis (Bremmer, 2009). Russia's innovation has been to combine its state capitalism with financial nationalism. Financial nationalist governments actively use their financial systems and policies to benefit national insiders, protect national wealth, promote national sovereignty and exert international influence. A key element of both multipolarity and financial nationalism is working to diminish the hegemony of the US dollar in international transactions, pricing, and reserves. This alternative vision has a political dimension as well, breaking not only with western economic liberalism but rejecting the liberal democratic form of government in favor of 'illiberal democracy' or socalled competitive authoritarianism. The Ukraine crisis and western sanctions have exacerbated these tendencies, entrenching multipolarity, financial nationalism and political illiberalism as key touchstones in Russian foreign economic policy making.

The rich literature on Russian economic policy after the global financial crisis has focused on diverse issues such as the Kremlin's domestic economic policy responses to the crisis (Cooper, 2011; Robinson, 2013), the need for economic modernization (Aleksashenko, 2012; Connolly, 2013; Mau, 2015), the impediments to institutional reform (Malle, 2012; Robinson, 2013), and the problems of natural resourcebased economic growth (Gaddy \& Ickes, 2010; Aleksashenko, 2012). Rutland (2016) has highlighted the role of economics in intellectual debates over Russian national identity, arguing that the Putin government has promoted alternative institutions such as the new Eurasian Economic Union (EEU) and Brazil, Russia, India, China and South Africa (the BRICS nations) in order to support a domestic state corporatism that could cut a middle path between national autarky and international integration. But while the EEU and BRICS complement Russia's developmental plans, this element of Russia's foreign economic strategy, we argue, is better seen as reflecting not only domestic aims but also the Putin government's geostrategic goals.

This study explores how Russia's foreign economic strategy of multipolarity relates to financial nationalism and political illiberalism at home. We move the discussion beyond Russia's domestic economic challenges and approach the issue from a broader perspective, one that integrates the Putin government's perception of the crisis as an opportunity to challenge the western-led international economic order with its long-term strategy of positioning Russia as an essential power broker in international politics. In doing so, we offer an overarching picture of Russia's alternative to the western order: it has interlocking domestic and international components that together aim to advance Russia's bid for leadership in an evolving global economic and political environment.

Finally, we argue that Russian leaders are doomed to frustration in their quest to assert international economic leadership. While Russia's alternative vision may be compelling to other states in the abstract, the messenger is less so. The
Russian government has the ability to shake up the existing international order but lacks the credibility, stability, or economic clout to lead the creation of a new one. This has important implications for the future of international economic cooperation and reform, as Russia's frustrations have increasingly turned it in reactive and confrontational directions.

\section{Multipolarity}

Multipolarity represents the cornerstone of Russia's foreign policy vision, not just in the economic sphere but more broadly as well. Certain elements of the Russian political elite, particularly top-level bureaucrats in the security services and foreign ministry, have systematically resisted US hegemony in international relations since the early 1990s. This group became known as the derzhavniki, pragmatic great-power nationalists who advocated a more assertive Russian role in the former Soviet sphere and in relations with the west (Jackson, 2003). Multipolarity rose to the level of foreign policy doctrine when former Foreign Intelligence Service director Yevgeny Primakov became Foreign Minister (1996-1998) and then Prime Minister (1998-1999) during Boris Yeltsin's second presidential term (Makarychev and Morozov, 2011). Primakov argued that to remain a great power, Russia needed to oppose North Atlantic Treaty Organization (NATO) enlargement in Eastern Europe and strengthen its ties with China and India.

With former Federal Security Service head Vladimir Putin's subsequent rise to power, multipolarity became entrenched as the 'ideological background of foreign policy thinking and practice' in Russia (Makarychev \& Morozov, 2011, p. 369). Putin brought many derzhavniki into his government - people like his former KGB colleagues Sergei Ivanov and Nikolai Patrushev - and restored the high-level status of the security services and military (Taylor, 2011). Taylor notes the strong overlap between derzhavniki and the siloviki, understood as officials with professional backgrounds in security, military and law enforcement. Russia's desire for a multipolar world burst further into public view when Putin criticized unipolarity at the 43rd Munich security conference in 2007 and when then-President Dmitrii Medvedev stated that in 2008 that 'the world should be multipolar' and 'a single pole is unacceptable' (President of Russia, 2008).

Indeed, before the global financial crisis Russia was already developing close ties with other states interested in challenging the US-led world order such as China, India, Venezuela, Syria and Iran (Hancock, 2007). As the crisis hit, Russia accelerated its drive to build a multipolar system of international relations. Russia's most recent Foreign Policy Concept reveals how the Kremlin perceived the crisis's effect on Russia's prospects for transforming the international order:

The current stage of world development is characterized by profound changes in the geopolitical landscape largely provoked or accelerated by the 
global financial and economic crisis. International relations are in the process of transition, the essence of which is the creation of a polycentric system of international relations. ${ }^{1}$

In the economic sphere, multipolarity has meant forging stronger cooperation among the BRICS, opening to the AsiaPacific region and intensifying integration efforts in the postSoviet space.

\section{Building the BRICS}

Russia's engagement with the BRICS is a central tool of its foreign economic agenda. The BRICS represent a core group of emerging powers that offered a genuine critique of the west's supremacy, espoused mutual noninterference in domestic politics, and offered Russia an opportunity to participate in an international economic bloc in which it had a nominally equal status. Consequently, the Russian government invested significant effort in transforming the group into more than just an informal talking shop. The central Urals city of Yekaterinburg hosted the first meeting of the BRICs Ministers of Foreign Affairs in 2008 and the first official BRICs leaders' summit in 2009. Since then, the BRICS heads of states have met in a different country every year and cooperation has continued to deepen. Under Russian influence the BRICS agenda widened over time as well, moving from its initial focus on the international financial architecture to encompass socioeconomic development, education and health, trade, agriculture, science and technology and international security. Putin (2012b) viewed the BRICS as representing 'a striking symbol of the transition from a unipolar world to a more just world order'.

The BRICS initiative has been instrumental in promoting Russia's multipolarity agenda in several ways. First, it has tempered Russia's international isolation after the March 2014 Crimean crisis. No BRICS country has criticized Russia's annexation of Crimea or coercive policies in Ukraine. This silence reinforces the Kremlin's world view. Russia has positioned itself as the Eurasian regional leader whose policies within that region should not be criticized by outside powers, and the other BRICS have behaved accordingly.

Second, Russia has used the BRICS to promote greater inclusivity in the international financial architecture. The BRICS countries collectively insisted that distributing power more equitably and bringing a wide range of countries into international governance structures would better reflect the realities of the international system (Huotari \& Hanemann, 2014). The BRICS countries were at the forefront in attempting to reform the IMF's voting structure and share weights in 2010. If the proposed changes were to be ratified, the BRICS's total voting shares in the IMF would rise to 10.3 per cent. The US, the IMF's main shareholder, has effectively blocked ratification so far despite widespread international approval of the proposal. ${ }^{2}$

Third, in response to such US recalcitrance Russia has increasingly worked with the BRICS to build alternatives to the current system. The final statement of the 2012 BRICS summit in New Delhi reflected this shift in emphasis by prominently calling for a broad-based international reserve currency system, fleshing out an earlier agreement for the countries' development banks to provide credit to each other in their national currencies, and proposing the creation of a BRICS development bank (Financial Times, 2012). The BRICS launched the New Development Bank (NDB) during its July 2015 summit in Ufa, Russia; the Bank's homepage states that it was founded 'as an alternative to the existing US-dominated World Bank and International Monetary Fund.' ${ }^{3}$ Expected to make its first loans in 2016, the NDB will have starting capital of $\$ 50$ billion. The Russian government has also signed on to China's new and much larger Asian Infrastructure Investment Bank as the third-largest shareholder after China and India.

The success, efficiency, and prospects of the BRICS as an international bloc are often debated (Cooper and Farooq, 2013; Goldstein, 2013; Chin, 2014; Huotari and Hanemann, 2014). Although the Russian government presents it as a club of equals, in reality China's GDP is larger than that of the other member states combined, and while the Russian ruble remains unattractive internationally the Chinese renminbi has become one of the top five currencies in the world (Noble, 2015). Moreover, while the BRICS share an interest in reducing US influence, they have had difficulty advancing a more positive agenda, as the birthing travails of the NDB indicate. Nevertheless, the BRICS will likely remain a significant platform for Russia's attempts to 'rebalance' the international financial system. Russia's long-term goal is to transform the group into a 'full-fledged mechanism of strategic cooperation on key international political and economic issues,' because ultimately the Kremlin believes that 'the association can potentially become a key element of a new system of global governance, first of all in the financial and economic areas' (President of Russia, 2013).

\section{The 'Pivot to Asia'}

The 'Pivot to Asia' represents another core element in Russia's push for multipolarity. While it includes increased ties to China both inside and outside the BRICS forum, it encompasses the Asia-Pacific region more broadly. Under Putin's leadership, for example, Russia has been an active participant in Asia-Pacific Economic Cooperation (APEC) summits and consolidated its ties with ASEAN countries. As Russia's Foreign Policy Concept aspirationally argues, 'the ability of the West to dominate the world economy and politics continues to diminish. The global power and development potential is now more dispersed and is shifting to the East, primarily to the Asia-Pacific region.'

Russia's Pivot to Asia reflects support among the Russian elite for a more Asian-style statist developmental model amidst the perceived global decline of western capitalism and liberal values. Influential scholar and Kremlin adviser Sergei Karaganov is the main advocate for re-orienting Russia's foreign policy and trade ties towards Asia. Karaganov (2013) has drawn attention to the 're-nationalization' of world politics and the central role that the Asia-Pacific 
region should play in Russia's quest for multipolarity. Indeed, Eurasian integration and opening to the Asia-Pacific would be 'Russia's New Globalization,' while an Asian development path would offer Russia unique opportunities in a quickly changing world (Barabanov and Bordachev, 2012). While Russia's liberal elite cautions that Russia's economic future still lies with the west (e.g., INSOR, 2011), this group has been progressively marginalized in Russian foreign policy circles, particularly since the Ukrainian crisis.

Beyond the intellectual debate, one practical reason for the Pivot to Asia has been to attract investment to Siberia and Russia's Far East (Kuhrt, 2012). In Putin's words, 'in the $21^{\text {st }}$ century, the vector of Russia's development will be the development of the East. Siberia and the Far East represent enormous potential' (President of Russia, 2012). To advance that goal, Putin's government established the Ministry for the Development of the Far East in May 2012 and chose Vladivostok, host city for the 2012 APEC summit, as the symbolic center for launching the Far East's economic development and integration with the Asia-Pacific region.

However, despite aspirations to use these growing Asian ties to facilitate technology transfer and modernization, in reality Russia's opening to Asia has been built primarily on its energy resource abundance. The Ukrainian crisis has intensified this development, with Russian economic upheaval and western sanctions leading the government to sign two concessionary energy deals with China. In May 2014 Russia signed a long-delayed gas deal worth $\$ 400$ billion during President Putin's visit to Beijing and then signed another in November to supply natural gas from western Siberia to China. In October 2014 the two governments signed a further 38 agreements on energy, trade, and finance that deepened their resource-based economic cooperation and provided for a currency swap of 150 billion renminbi to reduce their mutual dependence on the US dollar. While these agreements may help the Kremlin diversify its energy export markets, in the long run Russia's Pivot to Asia may also secure Russia's one-dimensional role as raw materials supplier to a more economically diverse and vibrant China. Russian leaders are not unaware of the risks, but seem willing to accept them.

\section{The EEU}

Russia has positioned itself as the Eurasian pole of a multipolar world by leading economic re-integration efforts in the postSoviet space. In 2009, Russian, Belarusian and Kazakh leaders agreed to form a Customs Union within the already existing but limited Eurasian Economic Community (EurAsEc). The Customs Union came into effect in 2010, with Russia's tariffs largely becoming the external tariffs of all union members. In 2012, the Customs Union became a Common Economic Space (CES) targeting the free movement of goods, labor, capital and services. Putin (2011) lauded the CES as a precursor to an eventual Eurasian Union, arguing that 'only together do our countries have the ability to become leaders of global growth and civilizational progress.' As he noted at the time:
We took the integration achievements in Europe as our reference model. We do have a few advantages of our own though... we have the Russian language that unites us as a natural common language of interstate communication, and this is a huge advantage. Furthermore, the infrastructure system - railways, energy sector infrastructure, aviation links - though we consider it still in need of further development, lays a solid base on which to build integration... Indeed, the situation is such that the heavens themselves incite us to integrate, and so this is what we are doing. ${ }^{4}$

In January 2015 the CES became the EEU, an entity modeled on the EU and encompassing the original three states plus Armenia and, as of August 2015, Kyrgyzstan; Russia expects Tajikistan to join as well. The Russian government has presented this latest Eurasian integration project as a natural postcrisis development, a response to the revealed dangers of being too dependent on western financial structures (Krickovic, 2014). According to Putin, regional groupings would have been better placed to weather the global economic turmoil, and deeper Eurasian integration will enable member states to have a stronger voice in the global economy. As the western powers demonstrated their inability to provide global collective goods, Russia would take on the responsibility of regional leadership (Krickovic, 2014). Russian political elites like Konstantin Kosachev, the chairman of the international affairs committee of the Federation Council, believe that the EEU will become the platform through which the postSoviet states will talk to the EU (TASS, 2015). The EEU is intended to counter the EU's Eastern Partnership and to boost Russia's global stance by making it the leader of a key regional economic organization (Shumylo-Tapiola, 2012; Cadier, 2014).

Restoring Russian dominance in the postSoviet space had long been on the agenda of Russia's derzhavnik foreign policy elite. As Jackson (2003) has shown, even in the early 1990s this group had proposed that Russia re-unite the postSoviet states through economic integration and security cooperation arrangements far deeper than those of the Commonwealth of Independent States created in December 1991. As a representative of this group, Putin worked towards increasing Russia's economic integration with other postSoviet states from the early stages of his presidency. In 2004, Viktor Khristenko, then deputy prime minister and now head of the Eurasian Economic Commission (the Eurasian equivalent of the European Commission), argued that only Eurasian integration could allow Russia to project its economic power in world markets, asserting that it would help the countries to consolidate their economic potential as well as 'broaden opportunities and improve competitive capacity' in trade with third countries (Khristenko, 2004). When Medvedev said, 'there are regions in which Russia has privileged interests' and with which Russia had 'special historical relations,' he echoed the near-consensus Russian attitude towards its postSoviet neighbors (President of Russia, 2008). 
This Russian-led integration has been both protectionist and coercive. Despite joining the World Trade Organization in 2012 Russia's tariffs remained relatively high for the region, and this has extended to its Eurasian integration agreements. For example, when Russia's tariffs became those of the Customs Union, it increased Kazakhstan's tariffs from an average of 6.7 per cent to 11.1 per cent on an unweighted basis (Isakova et al., 2013). More importantly, Russia has used economic coercion to prod recalcitrant states into joining, which reflects its increasingly zero-sum perception of foreign economic relations. The Russian government has systematically threatened and sanctioned postSoviet states wary of its economic integration project, especially those that pursued Association Agreements with the EU such as Moldova, Georgia and Ukraine. In fact, the Ukrainian crisis broke out in November 2013 when former President Viktor Yanukovych announced under Russian pressure that he would no longer pursue an EU Association Agreement. After the new Poroshenko government signed the EU agreement in July 2014, Russia blocked key Ukrainian exports. Russia had previously restricted imports from Moldova and Georgia, and had deported illegal migrants from those countries as punishment for noncooperation (Popescu, 2014). Russia has also threatened to send illegal Tajik migrants out of the country if Tajikistan's government did not acquiesce to integration on Russian terms (Parshin, 2015).

Russia's main source of leverage, though, has been natural gas prices. Since the Soviet collapse many neighboring states have relied on Russian gas sold at below-market rates, and Russian threats to raise these rates or cut supplies have teeth. Not long after Yanukovych's ouster Russia's state gas monopoly Gazprom raised Ukraine's gas prices and briefly cut off supplies for nonpayment, echoing similar actions after Ukraine's pro-European Orange Revolution in 2004. In January 2007 Russia doubled gas prices to Georgia and even cut supplies to its closest ally in the region, Belarus, for three days, which was interpreted as a clear sign of Putin's determined stance to ensure regional elites' loyalty to Russia (Balmaceda, 2007).

However, the EEU is unlikely to have enough economic firepower to boost Russia into a meaningful global role as a strong economic pole in a multipolar system. The EEU's members and potential members are far less wealthy than Russia, and the EEU is not well integrated economically. As of February 2013, Russia's key postSoviet partner states accounted for only 14 per cent of its foreign trade (Carneiro, 2013). A 2013 EBRD study of the Customs Union found that its trade creation effects were small while its trade diversion effects were more significant, testifying to its relatively zero-sum nature and boding ill for trade-driven growth in the EEU (Isakova et al., 2013). Less than 3 per cent of Russia's net outward foreign direct investment went to its current EEU partners between 2010-14, and only 3.6 per cent went to all the nonBaltic postSoviet states combined (Central Bank, 2015). All of the EEU members, including Russia, import most of their high valueadded products from more advanced economies (Inozemtsev, 2011).
Eurasian integration efforts have often been expensive for Russia as well. Russia has offered carrots along with the sticks, providing cheaper natural gas and other incentives to postSoviet states such as Belarus, Armenia and Kyrgyzstan in exchange for their cooperation in Russia's regional integration schemes. For example, in July 2013, Gazprom took over Kyrgyzstan's small gas pipeline network for a symbolic \$1 and in return assumed Kyrgyzstan's debts of $\$ 40$ million (Ott, 2014). In April 2015, Russia lowered Armenian gas prices after it joined the EEU (Armenpress, 2015). On a grander scale, Inozemtsev (2014) argues that Moscow's efforts to keep Belarus within its orbit cost it some $\$ 70$ billion from 2000 to 2013. Russia had to make major concessions to Belarus and Kazakhstan even when forming the original Customs Union (Barabanov, 2012). In short, Russia's attempt to be a regional economic leader has yielded lukewarm and pricey followers. While East European states clamored to join the EU often at real costs to themselves, Russia has often had to prod other postSoviet states to join the EEU.

The ongoing Ukraine crisis has further tested the Eurasian alliance. Events in Crimea and eastern Ukraine sent a strong signal to Russia's neighbors that the Kremlin might be willing to compromise their sovereignty as well, and the December 2014 Russian currency crisis had ripple effects throughout the region. Russia and the EEU remain popular among citizens of the EEU member states, but regional leaders have grown more cautious. For example, Belarusian President Lukashenko proposed resuming trade with Russia in US dollars, restored customs checkpoints between the two countries, verbally defended Ukraine's territorial integrity, and began to promote the Belarusian over the Russian language. As he bluntly stated, 'Yes, Russia is our brother and our friend. But you see how they sometimes behave. Therefore we need to be sure to diversify, whatever the cost' (Hille, 2015).

Karaganov and his colleagues (2015) have argued that we are witnessing 'the birth of the Central Eurasian Moment,' one that will make the region a nonwestern developmental powerhouse thanks to cooperation between the EEU and China's new 'One Belt, One Road' project. Krickovic (2014) has similarly argued that the EEU is a pragmatic collective response to power shifts in the global economy and could increase Russia's bargaining power vis-à-vis the west. But as falling world oil prices and western sanctions mire Russia ever more deeply in the stagflation trap, it can offer less to its neighbors. If Russia's EEU partners come to see their alliance as a threat rather than a boon to their long-term political and economic security, Russia may find itself a pole that repels rather than attracts, giving the EU and China the opportunity to draw the states of Russia's near abroad into their orbits instead.

\section{Financial nationalism}

Playing its desired postcrisis leadership role required Russia not only to build new transnational economic institutions and alliances, but also to present an attractive domestic 
development model to the outside world. Without a robust economy, Russia could not convincingly make a claim to economic leadership or draw others into its orbit via the soft power of economic influence. Unlike the broad appeal of multipolarity, however, Russian elites had comparatively more contested and less coherent visions for domestic economic development, visions ranging from liberal open-market policies to autarkic statism. In practice Vladimir Putin's government moved to institute state capitalism soon after his ascent to power, progressively bringing big business under government sway, but without initially compromising the country's economic openness.

After the global financial crisis, most Russian elites came to agree that Russia needed to modernize and diversify its economy away from natural resource dependence in order to achieve stable domestic growth and increase its economic influence internationally. The resulting conundrum was how to do so while simultaneously maintaining the state's ability to guide Russia's development. As Putin put it in a major policy statement, 'We need to find solutions to overcome our unilateral technological dependence... the successful experience of economic modernization in countries like Korea and China shows that a push in the right directions from the government is necessary' (Putin, 2012a). While not fully articulated and occasionally contested, we argue that the modernization imperative and Russia's desire to be the Eurasian pole in a multipolar system gave rise to a set of policies within the state capitalist system that we call financial nationalism.

Financial nationalism is an economic strategy that employs financial levers - including monetary policy, currency interventions, and other methods of interaction with local and international financial systems - to promote the nation's unity, autonomy and identity (Johnson and Barnes, 2015). It differs from economic nationalism in that it does not necessarily imply trade protectionism or withdrawal from global commodity markets (Pryke, 2012). Instead, financial nationalism puts an emphasis on the state's use of domestic financial resources and institutions - both public and private - to achieve state developmental goals and to enhance the state's relative autonomy within the international system. All of this is done in the name of the nation, in which state financial activism and national patriotism become conflated. While financial nationalist sentiment has had significant support in Russia since at least the mid-1990s, the global financial crisis, western sanctions, and the December 2014 ruble crisis progressively pushed it to the forefront of Russian domestic economic policy.

Financial nationalism requires monetary sovereignty. This can include promoting the national currency both domestically and internationally, as well as eschewing government accumulation of foreign debt. The Russian government had already undertaken an extensive de-dollarization campaign within Russia before the global financial crisis, touting the patriotic virtues of using the national currency (Johnson, 2008). It has since enhanced this agenda by issuing primarily ruble-based debt, encouraging banks to convert foreign currency loans into rubles, and embarking on a concerted effort to promote rubles rather than US dollars in export contract quotation and settlement (Suvorov, 2014). Putin has further noted that 'we need to be very careful about taking government loans. .. large debt always means a partial loss of national sovereignty. It creates a situation wherein any deterioration of the economic environment makes the country dependent on investors, international organizations, and lender nations, which then dictate what measures a government must take' (Putin, 2012a). Preserving monetary sovereignty has also involved stockpiling foreign exchange reserves, which rose from their post1998 crisis low of $\$ 11$ billion to a high of almost $\$ 600$ billion in early 2008. Indeed, before Russia's takeover of Crimea Putin was reported to have asked his aides if Russia's reserves were enough to buffer the country from potential western sanctions; when assured that they were, Putin proceeded with his annexation plans (Pismennaya et al., 2014).

Russian leaders have promoted ruble internationalization as a way to diversify the international monetary system and increase Russian financial leverage as well. While some claimed that the ruble had a future as a world currency, most agreed that the ruble should become the dominant currency in the postSoviet region (Johnson, 2013). Although Russia's EEU partners have viewed these efforts with skepticism, this has not deterred the Russian government from keeping the issue on the agenda in various ways (e.g., see Russia Today, 2015). One of Russia's first acts upon assuming control of Crimea was to replace the Ukrainian hryvnia with the Russian ruble (TASS, 2014). The Russian-supported separatist Georgian regions of Abkhazia and South Ossetia use the ruble as well, as does increasingly the embattled Donbass region in eastern Ukraine.

Financial nationalism further means showing preference to national insiders and financial institutions over foreign ones. This can include discrimination against foreign banks, preferential financing for domestic companies, as well as building and promoting domestic state-owned banks. Since the 1990s Russia has restricted foreign bank activity within its borders, not allowing foreigners to buy majority shares in Russian banks undergoing privatization and licensing foreign banks to operate only in limited ways and numbers. In addition, Russia never privatized its immense state savings bank (Sberbank) or the former Soviet foreign trade bank (Vneshtorgbank). After Russia's 1998 financial crisis led to multiple bank collapses and bailouts, state control over the sector increased significantly. Currently the five largest Russian banks are state controlled and dwarf the rest of the sector; only three foreign bank subsidiaries are in the top 20.5 The government employs the state-owned banks as investment tools, and runs Vneshekonombank as a traditional internal development bank. The government's current anticrisis plan involves recapitalization for stateowned and insider commercial banks, as well as additional support for Vneshekonombank's development activities (Myers, 2014; BNE, 2015).

Of course, many governments act to protect their own financial institutions. What makes Russia's financial nationalism more notable is that the state has also targeted 
domestic individuals and institutions with foreign financial ties as a disloyal fifth column. Since the global financial crisis it has engaged in a policy referred to as 'de-offshorization' of the elite, requiring government officials and business leaders to keep their personal wealth at home rather than in foreign bank accounts and foreign property. Russia has in essence imposed a financial loyalty test, in which the Putin government has punished elites possessing overseas financial resources as well as domestic NGOs receiving financial support from overseas (Putin, 2012b). ${ }^{6}$ The government has also imposed a punitive tax rate on earnings from foreignregistered companies controlled by Russian nationals (Baraulina et al., 2015). As Dmitri Trenin wryly observed, Putin 'publicly commended the US for sanctioning members of the Russian political and economic elites because it helped him with his own effort to nationalize them' (Trenin, 2014, p. 14).

Financial nationalism also involves using monetary policy to pursue state-led development and foreign policy goals. For this reason, financial nationalists distrust independent central banks. While the Central Bank of Russia (CBR) enjoys nominal legal independence and is one of the last bastions of economic liberalism, in practice the Putin government has used the CBR to support its economic and foreign policy on multiple occasions, a trend that has accelerated markedly since the Ukraine crisis. Credible reports indicated that the CBR withdrew over $\$ 100$ billion in US Treasury bills from the US Federal Reserve before the Crimean referendum, in anticipation of possible sanctions (BBC Monitoring, 2014). At the same time, the CBR provided over $\$ 27$ million in cash to sanctions-targeted SMP Bank, owned by close Putin associates (RosBusinessConsulting, 2014). After the December 2014 ruble crash, the government imposed informal capital controls, prevailed upon the largest state-owned exporters to sell foreign currency reserves to support the ruble, and insisted that future currency sales be coordinated with the government (Farchy, 2014). The Russian government also pressed the CBR to rebuild the foreign-exchange stockpile it spent to defend the ruble during the currency crisis, a policy which supports state-controlled export companies and monetary sovereignty but plays havoc with the CBR's preferred aim to control inflation.

Finally, financial nationalism implies turning away from international financial institutions dominated by the west. Although Russian skepticism of the IMF is longstanding, this skepticism has grown to encompass international financial institutions more broadly. For example, after Visa and Mastercard briefly denied service in March 2014 to Russian banks under US sanctions, the Russian government passed legislation mandating the creation of a separate national payments system and demanding that Visa and Mastercard deposit millions of dollars with the CBR in order to continue operations in the country. The CBR dutifully established the NSPK (National Card Payment System) in June 2014 and began processing payments through it in February 2015, an expensive proposition justified in the name of national financial autonomy and security (Krivobok, 2014). After receiving repeated sovereign credit-rating downgrades the
Russian government also declared that it would break ties with international ratings agencies and start its own national ratings agency instead (Russia Today, 2014). Legislation adopted in July 2015 charged the CBR with creating the new Credit Rating Agency of the Russian Federation by year's end. ${ }^{7}$ The Putin government envisions the spread of these institutions to the EEU as well, as further means through which Russia can extend its financial influence abroad.

The Russian government pairs this financial nationalism with political illiberalism, a governance system that has variously been called illiberal democracy, managed democracy, competitive authoritarianism and patronal presidentialism by scholars, and most famously sovereign democracy by former Kremlin chief ideologist Vladislav Surkov (Zakaria, 1997; Wegren and Konitzer, 2007; Levitsky and Way, 2010; Hale, 2005; Surkov, 2009). The chief characteristics of this political system include managed elections, state dominance over the media, demonization of regime opponents, conflation of the state and the nation in government discourse, and an extensive political patronage network (financed by Russia's resource wealth) with the president sitting at the top of the so-called 'power vertical.' Many Russian elites present this system as a more historically and culturally appropriate political model for Eurasia than western liberal democracy, which was perhaps unfairly but quite thoroughly discredited in the eyes of the Russian public during the turbulent Yeltsin era. For its part, the Russian public has supported Putin's political leadership, rewarding him with approval ratings of 89 per cent as of June $2015 .^{8}$ The public generally applauded his efforts to restore Russian influence internationally, welcomed the annexation of Crimea, and, in keeping with Russian state media messaging, identified the west as the aggressor in trying to pull Ukraine away from Russia, keeping Russia economically weak, and fomenting antiRussian sentiment in neighboring states.

\section{Russia's power paradox}

The Putin government's policies of multipolarity, financial nationalism, and political illiberalism are symbiotic, with the state using its control over financial flows to build and maintain power and to project its influence abroad, all justified with a strong dose of great power nationalist sentiment. Western sanctions imposed after the Crimea takeover have further shifted power away from Russia's liberals, tilting the balance toward the derzhavniki and emboldening formerly marginalized economists such as Sergei Glazyev who have long advocated financial nationalism and regional economic integration (Glazyev, 2014; Rutland, 2016). Multipolarity, financial nationalism and political illiberalism as concepts also hold fairly wide appeal in the postcrisis world, as countries as diverse as Hungary and China demonstrate. It is unsurprising that policies to protect national finance yet encourage regionally based economic integration would seem attractive to many after the revealed weaknesses and inequities of the international financial system and the ongoing tribulations of the euro. 
Nevertheless, Russian elites have become increasingly frustrated in their bid to position Russia as a Eurasian pole and attractive model of nonliberal development in the postcrisis international system. The most recent Pew Global Attitudes poll found that few countries viewed Russia or Vladimir Putin favorably (Stokes, 2015). In order for Russia to successfully promote itself as a systemic pole, it must be seen as an attractive, politically stable economic powerhouse with a sustainable development model. However, far from serving as a potential engine of development, Russia's illiberal political-economic system represents the major obstacle to the country's modernization (Johnson, 2012; Ledeneva, 2013). By privileging a small network of loyal domestic elites and informal rules, it promotes economic uncertainty and stifles innovation. Russia's economy has stagnated since the global financial crisis, and as high capital flight and low ruble savings figures suggest, while Russians may support their president even they do not necessarily trust their country's economic institutions.

This gap between Russia's economic leadership aspirations and capabilities threatens regional stability in Eurasia and the postcrisis international order more broadly. The derzhavniki view Russia as the inevitable Eurasian pole because of its regional economic and military superiority, its large US dollar reserves, and its vast natural resources. But Russia's economic instability and its coercive actions in Ukraine and elsewhere have frightened even its EEU allies, while China's increasingly assertive economic role in Central Asia and within the BRICS threatens to marginalize Russia in its own backyard and on the world stage. Indeed, despite conciliatory noises from both sides, China's latest 'One Belt, One Road' strategy for expanding its influence in Central Asia seems destined to conflict with the Russian government's ambitions for the EEU.

The Ukraine crisis and western sanctions have made Russia's modernization and diversification goals even more distant. First Deputy Prime Minister Shuvalov has optimistically mused, 'We have experience, like with how South Africa developed under sanctions or how Chile developed in difficult conditions. Is it possible to create a modern economic system amid political difficulties? The answer - it is' (Interfax, 2015). But as Russia has become progressively cut off from western financing and technologies, as Putin's inner circle has shrunk to exclude most liberal economic voices, and as economic problems brought on by sanctions and low oil prices threaten Putin's ability to keep adequate resources flowing through his patronage network, such optimism rings hollow.

At the same time, western sanctions have reinforced the power of the derzhavniki. As much of the Putin government and Russian public revel in antiAmericanism, Russian economic liberals who had previously championed engagement with global political and economic structures are being squeezed out. Ultimately, the sanctions jeopardize Russia's hard-won integration in the international financial system, integration that is vital for sustained Russian economic development. The resulting situation challenges not only Russia and its neighbors, but also the US and the EU. The west must devise a new strategy towards Russia - one that takes into account Russia's search for great power status and leadership in Eurasia without at the same time undermining international economic cooperation or forcing Russia's smaller neighbors to choose sides.

\section{Notes}

1. Foreign Policy Concept of the Russian Federation, 12 February 2013 [online]. Available from: http://www.mid.ru/brp_4.nsf/0/76389FEC1681 89ED44257B2E0039B16D [Accessed: 28 May 2015].

2. Although the US executive branch approved the reforms in 2010 , the US Congress has yet to do so. See https://www.imf.org/external/np/ $\mathrm{sec} / \mathrm{misc} /$ consents.htm for the current status of the reform proposals.

3. See http://ndbbrics.org/

4. Vladimir Putin, Meeting with Valdai International Discussion Club par ticipants, 25 October 2012 [online]. Available from: http://eng.kremlin. ru/news/4564 [Accessed 2 May 2015].

5. See The Banker's rankings at http://www.thebanker.com/Banker-Data/ Banker-Rankings/Top-100-Russian-banks-ranking-2014-Russia-seeks-tostay-on-solid-ground?ct=true [Accessed 13 August 2015].

6. Putin extended his nationalization efforts to bilateral aid, cancelling every US-Russian cooperation agreement that 'listed the US as a donor country and Russia as a recipient of US aid... For the Kremlin, government policies funded by foreign money were no longer tolerable.' (Trenin, 2014).

7. See Bank of Russia Press Service, 'O proekte po sozdaniiu novogo kreditnogo reitingovogo agenstva [On the project of the creation of a new credit rating agency],' 24 July 2015 [online]. Available from: http://www.cbr.ru/press/pr.aspx?file=24072015_122628if2015-07-24T12 23_34.htm [Accessed 21 November 2015].

8. Levada Center monthly poll [online]. Available from: http://www.leva da.ru/eng/indexes-0 [Accessed 13 August 2015].

\section{References}

Aleksashenko, S. (2012) 'Russia's Economic Agenda to 2020', International Affairs, 88 (1), pp. 31-48.

Armenpress (2014) 'Russia to reduce gas price for Armenia', 28 April [online]. Available from: http://armenpress.am/eng/news/803624/ russia-to-reduce-gas-price-for-armenia.html [Accessed 12 August 2015].

Balmaceda, M. M. (2007) Energy Dependency, Politics and Corruption in the Former Soviet Union: Russia's Power, Oligarchs' Profits and Ukraine's Missing Energy Policy, 1995-2006. New York, NY: Routledge.

Barabanov, O. and Bordachev, T. (2012) 'Toward the Great Ocean, or the New Globalization of Russia', Valdai Discussion Club Analytical Report [online]. Available from: http://valdaiclub.com/publication/45700.html [Accessed: 1 February 2015].

Barabanov, O. (2012) 'Customs Union and Eurasian Union: Problems on the road to integration,' 11 April. Valdai Club [online]. Available from: http://valdaiclub.com/near_abroad/41060.html [Accessed: 15 January 2015].

Baraulina, A., Sazonov, A. and Fedorinova, Y. (2015) 'Richest Russians Repatriate Assets as Putin Turns Tax Screw', Bloomberg, 20 January [online]. Available from: http://www.bloomberg.com/news/2015-0119/richest-russians-repatriate-assets-after-putin-turns-tax-screw.html [Accessed 28 May 2015].

Bremmer, I. (2009) 'State Capitalism Comes of Age', Foreign Affairs, 88 (3), pp. 40-55.

BBC Monitoring (2014) 'Russia may have withdrawn 105bn dollars from USA ahead of sanctions - paper', 20 March.

BNE (2015) 'Russia prepares RUB1.375 trillion anticrisis plan', Business New Europe IntelliNews, 22 January. Available from: http://www.intelli news.com/russia-prepares-rub1-375-trillion-anti-crisis-plan-500443266/ ?archive=bne [Accessed 21 November 2015] 
Cadier, D. (2014) 'Eastern Partnership vs Eurasian Union? The EU-Russia Competition in the Shared Neighbourhood and the Ukraine Crisis', Global Policy, 5 (1), pp. 76-85.

Carneiro, F. G. (2013) 'What Promise Does the Eurasian Customs Union Hold for the Future?' Washington, DC: World Bank [online]. Available from: http://documents.worldbank.org/curated/en/2013/02/17394402/ promises-eurasian-customs-union-hold-future [Accessed: 1 February 2015].

Central Bank of the Russian Federation. 2015. 'External Sector Statistics' [online]. Available from: http://www.cbr.ru/eng/statistics/?Prtid=svs \&ch=PAR_31141\#Checkedltem [Accessed: 12 August 2015]

Chin, G. (2014) 'The BRICS-Led Development Bank: Purpose and Politics Beyond the G20', Global Policy, 5 (3), pp. 3663-73.

Colton, T. J. \& McFaul, M. (2003) Popular Choice and Managed Democracy: The Russian Elections of 1999 and 2000. Washington, DC: Brookings Institution Press.

Connolly, R. (2013) 'State-Industrial Policy in Russia: The Nanotechnology Industry', PostSoviet Affairs, 29 (1), pp. 1-30.

Cooper, J. (2011) 'Russia and Global Financial-Economic Crisis,' in J. Wilhelmsen and E. Wilson Rowe (eds) Russia's Encounter with Globalisation: Actors, Processes and Critical Moments. Houndmills, Basingstoke, Hampshire, New York, NY: Palgrave Macmillan, pp. 71-96.

Cooper, A. F. \& Farooq, A. B. (2013) 'BRICS and the Privileging of Informality in Global Governance', Global Policy, 4 (4), pp. 428-433.

Crouch, C. (2011) The Strange NonDeath of Neo-Liberalism. London: Polity.

Farchy, J. (2014) 'Moscow orders state-owned exporters to sell foreign currency', Financial Times, 23 December [online]. Available from: http://www.ft.com/intl/cms/s/0/09b78bfa-8aa7-11e4-8e24-00144feabd c0.html?siteedition=intl\#axzz3N73JNbmp [Accessed 15 January 2015].

Financial Times (2012) 'China offers other BRICs renminbi loans', 7 March. Available from: http://www.ft.com/intl/cms/s/0/3e46ac04-67fd11e1-978e-00144feabdc0.html\#axzz3s9tUt0A9 [Accessed 21 November 2015].

Gaddy, C. G. and Ickes, B. W. (2010) 'Russia after the Global Financial Crisis', Eurasian Geography and Economics, 51 (3), pp. 281-311.

Glazyev, S. (2014) 'The Threat of War and the Russian Response How to Lead a Coalition and Avoid a Global Conflict', Russia in Global Affairs, 23 September [online]. Available from: http://eng.globalaffairs.ru/num ber/The-Threat-of-War-and-the-Russian-Response-16988 [Accessed 11 August 2015].

Goldstein, A. (2013) 'The Political Economy of Global Business: the Case of the BRICs', Global Policy, 4 (2), pp. 162-172.

Hale, H. E. (2005) 'Regime Cycles: Democracy, Autocracy, and Revolution in Post Soviet Eurasia', World Politics, 58 (1), pp. 133-165.

Hancock, K. J. (2007) 'Russia: Great Power Image Versus Economic Reality', Asian Perspective, 31 (4), pp. 71-98.

Helleiner, E. (2014) The Status Quo Crisis: Global Financial Governance after the 2008 Meltdown. New York, NY: Oxford University Press.

Hille, K. (2015) 'Cracks exposed in Vladimir Putin's dream of building a Eurasian economic powerhouse', Financial Times, 9 January. Available at: http://www.ft.com/intl/cms/s/0/657967da-9725-11e4-845a-00144 feabdc0.html\#axzz3s9tUt0A9 [Accessed 10 January 2015]

Huotari, M. and Hanemann, T. (2014) 'Emerging Powers and Change in the Global Financial Order', Global Policy, 5 (3), pp. 298-310.

Inozemtsev, V. (2011) 'Novyy proyekt integratsii osnovan na oshchushchenii slabosti i marginalizovannosti kazhdogo iz yeye uchastnikov', Izvestiya, 1 November. Available at: http://izvestia.ru/news/505572 [Accessed 21 November 2015].

Inozemtsev, V. (2014). 'Mneniye: Chto dast Rossii Soyuz s Aziyey', RBK: Ezhednevnaya delovaya gazeta, 16 June. Available from: http://rbc daily.ru/economy/562949991722596 [Accessed 21 November 2015].

INSOR (2011) Attaining the Future: Strategy 2012. Moscow: Institute for Contemporary Development.

Interfax (2015) 'Russia now in extremely difficult economic condition, but could use this for reform - Shuvalov', 23 January.
Isakova, A., Koczan, Z., and Plekhanov A. (2013) 'How Much Do Tariffs Matter? Evidence from the Customs Union of Belarus, Kazakhstan and Russia', January [online]. Available from: http://www.ebrd.com/ downloads/research/economics/workingpapers/wp0154.pdf [Accessed 14 December 2014].

Jackson, N. J. (2003) Russian Foreign Policy and the CIS: Theories, Debates and Actions. London: Routledge.

Johnson, J. (2008) 'Forbidden Fruit: Russia's Uneasy Relationship with the Dollar', Review of International Political Economy, 15 (3), pp. 377 396.

Johnson, J. (2012) 'Mission Impossible: Modernization in Putin's Russia', PONARS Eurasia Policy Memo \#196 [online]. Available from: http:// www.ponarseurasia.org/memo/mission-impossible-modernization-russ ia-after-global-financial-crisis [Accessed 13 August 2015].

Johnson, J. (2013) 'Russia: International Monetary Reform and Currency Internationalization', Centre for International Governance Innovation $(\mathrm{ClGl})$, Asian Development Bank, and Hong Kong Institute for Monetary Research, pp. 1-27. Available at: https://www.cigionline.org/ publications/2013/6/russian-federation-international-monetary-reformand-currency-internationalizati [Accessed 16 September 2015].

Johnson, J. and Barnes, A. (2015) 'Financial Nationalism and Its International Enablers: The Hungarian Experience', Review of International Political Economy, 22 (3), pp. 535-569.

Karaganov, S. (ed.) (2015) 'Toward the great ocean - 3: Creating Central Eurasia. The Silk Road Economic Belt and the priorities of the Eurasian states' joint development.' Valdai Discussion Club Analytical Report [online]. Available from: http://valdaiclub.com/publications/ reports/toward_the_great_ocean_3_creating_central_eurasia/ [Accessed 12 August 2015].

Khristenko, V. (2004) 'Making Headway into Integration', Russia in Global Affairs, 3 (1) [online]. Available from http://eng.globalaffairs.ru/ number/n_2573 [Accessed 12 December 2014].

Krickovic, A. (2014) 'Imperial Nostalgia or Prudent Geopolitics? Russia's Efforts to Reintegrate the PostSoviet Space in Geopolitical Perspective', PostSoviet Affairs, 30 (6), pp. 503-528.

Krivobok, R. (2014) 'Central Bank of Russia Establishes National Card System Operator', RIA Novosti, 19 June [online]. Available from: http:// en.ria.ru/russia/20140619/190617988/Central-Bank-of-Russia-EstablishesNational-Card-Payment-System.html [Accessed 12 December 2014].

Kuhrt, N. (2012) 'The Russian Far East in Russia's Asia Policy: Dual Integration or Double Periphery?', Europe-Asia Studies, 64 (3), pp. 471-493.

Ledeneva, A. V. (2013) Can Russia Modernise?: Sistema, Power Networks and Informal Governance. Cambridge: Cambridge University Press.

Levitsky, S. \& Way, L. A. (2010) Competitive Authoritarianism: Hybrid Regimes after the Cold War. Cambridge: Cambridge University Press.

Makarychev, A., and Morozov, V. (2011) 'Multilateralism, Multipolarity, and Beyond: A Menu of Russia's Policy Strategies', Global Governance' 17 (3), pp. 353-373.

Malle, S. (2012) 'The Policy Challenges of Russia's PostCrisis Economy', Post Soviet Affairs, 28 (1), pp. 66-110.

Mau, V. (2015) 'Between crises and sanctions: Economic Policy of the Russian Federation', PostSoviet Affairs, forthcoming, doi: 10.1080/ 1060586X.2015.1053723. Available from: http://www.tandfonline.com/ doi/abs/10.1080/1060586X.2015.1053723?journalCode=rpsa20\#.VIYTVX sgp0k [Accessed 25 November 2015].

Myers, S. L., Becker, J. and Yardley, J. (2014) 'Private Bank Fuels Fortunes of Putin's Inner Circle', New York Times, 27 September. Available from: http://www.nytimes.com/2014/09/28/world/europe/it-pays-tobe-putins-friend-.html?_r=0 [Accessed 21 November 2015].

Noble, J. (2015) 'Renminbi Joins Top Five Most-Used Currencies', Financial Times, 28 January. Available from: http://www.ft.com/intl/ cms/s/0/6b8441f0-a69c-11e4-89e5-00144feab7de.html\#axzz3s9tUt0A9 [Accessed 21 November 2015].

Ott, S. (2014) 'Russia tightens control over Kyrgyzstan', The Guardian, 18 September [online]. Available from: http://www.theguardian.com/ 
world/2014/sep/18/russia-tightens-control-over-kyrgyzstan [Accessed 15 January 2015].

Parshin, K. (2015) 'Eyeing Tajikistan's Weak Spot, Russia Presses for Integration', Eurasia Net, 15 January [online]. Available from: http:// www.eurasianet.org/node/71631 [Accessed 15 January 2015].

Pismennaya, E., Arkhipov, I. and Cook, B. (2014) 'Putin's Secret Gamble on Reserves Backfires Into Currency Crisis', Bloomberg News, 17 December [online]. Available from: http://www.bloomberg.com/ news/articles/2014-12-17/putin-s-secret-gamble-bet-on-ukrainebackfires-in-ruble-crisis [Accessed 11 August 2015].

Popescu, N. (2014) 'Eurasian Union: The Real, the Imaginary, and the Likely', Chaillot Paper, No. 132. Brussels: EU Institute for Security Studies [online]. Available from: http://www.iss.europa.eu/publica tions/detail/article/eurasian-union-the-real-the-imaginary-and-the-likely/ [Accessed 14 January 2015].

President of Russia (2008) 'Interview Given by Dmitry Medvedev to Television Channels Channel One, Rossiya, NTV', 31 August [online]. Available from: archive.kremlin.ru/eng/text/speeches/2008/08/31/1850_ type82912type82916_206003.shtml [Accessed 10 December 2014].

President of Russia (2012) 'Address to the Federal Assembly', 12 December [online]. Available from: http://en.kremlin.ru/events/pre sident/news/17118 [Accessed 10 December 2014].

President of Russia (2013) 'Concept of Participation of Russian Federation in BRICS' [online]. Available from: http://static.krem lin.ru/media/events/eng/files/41d452b13d9c2624d228.pdf [Accessed 28 December 2014].

Pryke, S. (2012) 'Economic nationalism: Theory, history and prospects', Global Policy, 3 (3), pp. 281-291.

Putin, V. V. (2011) 'Novyi integratsionnyi proekt dlia Evrazii budushchee, kotoroe rozhdaetsia segodnia', Izvestiia, 3 October [online]. Available from: http://izvestia.ru/news/502761 [Accessed 3 July 2015].

Putin, V. V. (2012a) 'Economic Tasks', Vedomosti, 30 January. Available in English translation from: http://archive.premier.gov.ru/eng/events/ news/17888/ [Accessed 21 November 2015].

Putin, V. V. (2012b) 'Rossia i meniaiushchiisia mir', Moskovskiye Novosti, 27 February (online). Available from: http://www.mn.ru/politics/78738 [Accessed 21 November 2015].

RIA Novosti (2009) 'Rubl' i yuan': kto blizhe k rezervnoi valyute?', RIA Novosti, 6 June [online]. Available from: http://news.mail.ru/eco nomics/2642989/ [Accessed 15 January 2015].

Robinson, N. (2013) 'Russia's Response to Crisis: The Paradox of Success', Europe-Asia Studies, 65 (3), pp. 450-472.

RosBusinessConsulting (2014) 'CBR injects $\$ 27 \mathrm{~m}$ of cash in sanctions-hit SMP Bank', 24 March. Accessed via Factiva, 15 January 2015.

Russia Today (2014) 'Russia: Moving away from international rating agencies only "question of time"', 14 May [online]. Available from: http://rt.com/business/158856-russia-raitings-agency-ministry/ [Accessed 12 December 2014].

Russia Today (2015) 'Putin says dump dollar,' 1 September [online]. Available from: https://www.rt.com/business/313967-putin-says-dumpdollar/ [Accessed 16 September 2015].

Rutland, P. (2016) 'The role of economics in Russian national identity debates', in P. Kolsto and H. Blakkisrud (eds.), The New Russian Nationalism: Imperialism, Ethnicity and Authoritarianism 2000-15. Edinburgh: Edinburgh University Press.

Shumylo-Tapiola, O. (2012) 'The Eurasian Customs Union: Friend or Foe of the EU?' The Carnegie Papers. Brussels: Carnegie Europe.

Stokes, B. (2015) 'Russia, Putin Held in Low Regard around the World', Pew Research Center, 5 August [online]. Available from: http:// www.pewglobal.org/2015/08/05/russia-putin-held-in-low-regard-aroundthe-world/ [Accessed: 13 August 2015].

Surkov, V. I. (2009) 'Nationalization of the future: Paragraphs pro sovereign democracy', Russian studies in philosophy, 47 (4), pp. 8-21.

TASS (2015a) 'Pervym shagom vlastei Kryma stanet perekhod $v$ rublevuiu zonu,' 16 March. Available from: http://tass.ru/mezhdun arodnaya-panorama/1051555 [Accessed 21 November 2015]

TASS (2015b) 'EAES v budushchem mozhet stat' ploshchadkoy dlya ravnopravnogo sotrudnichestva s ES', 3 January. Available from: http://tass.ru/politika/1684060 [Accessed 21 November 2015].

Taylor, B. D. (2011) State Building in Putin's Russia: Policing and Coercion after Communism. New York, NY: Cambridge University Press.

Trenin, D. (2014), 'Russia's Breakout From the PostCold War System: The Drivers of Putin's Course', Carnegie Moscow Center, 22 December.

Wegren, S. K. \& Konitzer, A. (2007) 'Prospects for managed democracy in Russia', Europe-Asia Studies, 59 (6), pp. 1025-1047.

Zakaria, F. (1997) 'The rise of illiberal democracy', Foreign Affairs, 76 (6), pp. $22-43$.

\section{Author Information}

Juliet Johnson, Professor of Political Science at McGill University. Her research focuses primarily on money and banking in postcommunist Europe, as well as on postcommunist memory politics. Her book Priests of Prosperity: How Central Bankers Transformed the Postcommunist World is forthcoming from Cornell University Press in February 2016.

Seçkin Köstem, Ph.D. candidate in Political Science at McGill University, a Research Fellow at the Center for Foreign Policy and Peace Research at Bilkent University, and Managing Editor of the Review of International Political Economy. His research focuses on the role that national identity conceptions held by ruling elites play in the formation of foreign economic policies in Russia and Turkey. 